\title{
Executive Compensation: Pay-for-Performance in High-Technology Firms
}

\author{
Paula Faria, Francisco Vitorino Martins, Elísio Brandão \\ University of Porto, Porto, Portugal
}

\begin{abstract}
This study examines the relationship between corporate performance and the Chief Executive Officer (CEO) compensation in high-technology firms in the S\&P 500. The total short- and long-term CEO compensation in high-technology was compared with other industrial sectors from standard classification codes and tested in terms of corporate performance. The ExecuComp database was used to find the variables and to create a sample of firms between 2004 and 2010. Important corporate performance variables are used in this work, such as assets, employees, sales, net income, and earnings per share (EPS), as reported by the firms for each year. A panel data GLS with a fixed effect model for time is estimated that describes total compensation for the period between 2004 and 2010. The result was aligned with the theory of executive compensations to address agency problems and to examine CEO pay-for-performance. The main objective of this paper is to consistently demonstrate that the performance is determined for the total CEO compensation for short- and long-term periods and to examine whether the total remuneration paid to CEOs in high-technology firms in the S\&P 500 is related to corporate finance. This work provides a better understanding of the relationship between compensation and performance in high-technology firms. Results suggest that high-tech firms tend to use more sophisticated performance measurements to determine CEO compensation.
\end{abstract}

Keywords: corporate finance, CEO compensation, accounting, performance

While most management scholars would agree that technological innovation is a key source for competitive advantage in high-technology firms and that top executives in those firms should be rewarded accordingly, little is known about which executive pay policies are more appropriate for those organizations to promote such goals. The high-technology sector plays a pivotal role in the new economy and has become the major source of employment and productivity growth over the last years. Innovativeness is also one of the fundamental instruments for growth strategies to enter new markets and to provide the company with a competitive edge.

The purpose of this study is to investigate the relation between the Chief Executive Officer (CEO) pay and the value, performance, and behavior of the firms in terms of innovation in high-technologies. This work will contribute to this subject as it introduces a new measurement pertaining to the relationship between the CEO and the other members of the top executive team. Furthermore, this paper studies the relation between this

Paula Faria, M.Sc., School of Economics and Management and INESC TEC, University of Porto.

Francisco Vitorino Martins, Ph.D., School of Economics and Management, University of Porto.

Elísio Brandão, Professor of Finance, School of Economics and Management, University of Porto.

Correspondence concerning this article should be addressed to Paula Faria, Rua Dr. Roberto Frias, Porto, 4200-465, Portugal. E-mail: 100427016@fep.up.pt. 
measurement and the performance and behavior of firms in terms of innovation. For that, this paper will use a new data sample of high-tech companies in the S\&P 500 for the period between 2004 and 2010.

In their paper, entitled "The CEO Pay Slice", Bebchuk, Cremers, and Peyer (2011) studied the relation between the CEO pay slice and the value, performance, and behavior of public firms, demonstrating a rich set of relations between these aspects. Furthermore, Makri, Lane, and Gomez-Mejia (2006) reported empirical evidence that high-technology firms that use outcome-based and behavior-based performance criteria to reward executives exhibit better market performance than those that do not. Their research on innovation CEO pay linkages in high-technology firms has focused on aligning pay with the quantity of innovation inputs (R\&D spending) and outputs (number of patents). In fact, authors show the importance of the quality of innovation outputs. They argue that for CEO pay-performance relations in high-technology firms these views are not incompatible, but represent two sides of the same coin (Makri, Lane, \& Gomez-Mejia, 2006).

The theory summarizes that executive pay should be designed by the board to maximize shareholder value. The level and structure of executive pay have already been discussed in the literature, resulting in three dominant views. One strand of literature studies the pay-to-performance sensitivity. Jensen and Murphy (1990a) showed that CEO wealth is only weakly related to firm performance. Subsequently, another view provides abundant evidence of a significant increase in CEO pay in both absolute and relative terms since 1990, which is consistent with a better alignment of interests between managers and shareholders (Murphy, 1999; Bebchuk \& Fried, 2004; Frydman, 2009). Another important strand of literature explains the level and the functional form of pay as skimming issues rather than optimal contracting outcomes.

The inner workings of a top executive team and their importance for firm performance and innovation are hard to observe or quantify. As previously described, in order to promote firm growth, sustainable advantage, innovation and performance behavior, the role of the CEO is fundamental. Furthermore, over the last years, due to the effects of the global financial crisis, the role of the CEO has been called into question, as well as their behavior and their pay-compensation as a result of their performance and objectives. Moreover, it is essential to maintain confidence in the executive for there to be a balance between the institutions that foster the best conditions for their employees and maximize the profits of their shareholders. For these reasons, and because this subject is pertinent, it is interesting to examine these issues and contribute to the enrichment of research in this area.

This study explores the performance determinants of the high-tech and all other CEO pays for long- and short-term periods. This work also attempts to examine the systematic difference in CEO pays and the performance expectations of high-tech firms and others firms. Furthermore, this paper attempts to examine how high-tech and other CEO pays are related to various performance measurements, such as assets and employment in their specificity in high-tech firms, sales growth, operating income before depreciation, net income before extraordinary items and discontinued operations, and earnings per share (EPS).

This work is organized as follows: Section two contains a revision of the main theories in the literature, as well as an analysis of executive compensation in order to address agency problems. Furthermore, this section provides an analysis in order to examine CEO pays for performance. Section three explains the research hypotheses and section four presents the methodology, sample, and data collection for the regression estimation, as well as the results of the econometric model in order to assess the influence that firm performance has on executive compensation. Lastly, the main conclusions are discussed, as well as some limitations and new perspectives for future research. 


\section{Corporate Performance and CEO Compensation}

In the period between 1970 and 2005, it was observed that executive compensations increased tremendously. The underlying reasons for these executive compensations need to be discussed and analyzed so as to provide a better understanding on this matter as we move into the future. Much literature on executive compensation has emerged since Jensen and Meckling (1976) published their work. According to Jensen and Murphy (1990b):

There are serious problems with CEO compensation, but "excessive" pay is not the biggest issue. The relentless focus on how much CEOs are paid diverts public attention from the real problem-how CEOs are paid. In most publicly held companies, the compensation of top executives is virtually independent of performance. (p. 138)

\section{Executive Compensations to Address Agency Problems}

The emergence and general acceptance of the agency theory and the parallel research on executive compensation began in the early 1980s. It was the evolution of the modern corporation with ownership separation and control that undermined the agency theory. Early studies in this area focused on documenting the relation between CEO pay and company performance.

The problem of managerial power is analyzed in modern finance as an agency problem. The discussion of executive compensation must proceed with the fundamental agency problem afflicting management decision-making as background. According to Jensen and Murphy (1990a), there are two approaches to agency problems. The authors state that there is an optimal contracting approach, which is when boards use design compensation schemes to maximize shareholder value with efficient incentives. To connect the agency problem and the executive compensation, the authors use the managerial power approach, when this connection is seen as an integral part of the agency problems. It is important to remember that the principal-agent problems treat the difficulties that arise under conditions where information is incomplete and asymmetric whenever a principal hires an agent (Jensen \& Murphy, 1990a). The agency theory is directed as an agency relationship between principal and agent in which one part-the principal - delegates work to another - the agent, who performs that work. It is created at any company that is not owned by its manager. This theory may be summarized as having two problems: Firstly, the agency problems arise when the desires or goals of the principal and agent are conflicting and when it is difficult or expensive for the principle to verify what the agent is doing; the second is the problem of risk sharing that arises when the principal and agent have different attitudes towards risk. Maybe the agent and the principal prefer different actions and different risk choices. Jensen and Meckling (1976) suggested that the agents of a company have the tendency to expropriate from the company because the benefits are higher than the cost as such costs are shared or undertaken by various shareholders. Therefore, there should be a balance, and both parties' participation constraints should be satisfied. According to them, the agency problem existed in all organizations and cooperatives, including universities (Jensen \& Meckling, 1976). The agency problem is a classic problem in corporate governance as a result to motivate executives to do what is best for their company when they themselves do not own the company. It is necessary to anticipate the agency problem as because of it company investors may try to specify how the manager should act. Furthermore, it is necessary to analyze this problem because the owner may not be able to predict the business and may not know the best action for their manager (Maxim, Shleifer, \& Vishny, 1996). The contracts signed between shareholders and managers are usually general, specifying broad goals and 
the division of profits. These contracts do not specify how managers should behave in specific business situations.

Some authors see the weakness of shareholder rights more generally and warn shareholders and their advisers to focus on the corporate governance provisions that really matter for the firm's value (Bebchuk, Cohen, \& Ferrell, 2009; Cremers \& Nair, 2005). To help solve the apparent theoretical paradox in agency predictions on the normative consequences of performance-based pay, it is possible to create a common fate for the principal and the agent, or to make the agent overly conservative. The agency theory has been the foundation for both positive and negative answers to the key question: Does incentive compensation help high-technology firms attain higher subsequent performance levels (Makri, Lane, \& Gomez-Mejia, 2006)?

Some authors assume CEOs to be more powerful when they serve as chair of the board, when they are the only member of the board, and when they have the status of a founder (Adams, Almeida, \& Ferreira, 2005).

\section{Examining CEO Pay-for-Performance}

For Murphy (1999), the components of CEO pay are substantially heterogeneous in pay practices across firms and industries. Most executive pay packages contain four basic components: a base salary, an annual bonus linked to accounting performance, stock options, and long-term incentive plans. Moreover, executives participate in employee benefit plans and also receive special benefits, such as life insurance and supplemental executive retirement plans. Today the packages of most CEO compensations have many components, which include payouts for long-run incentive plans, restrict option grants and restrict stock grants, pension plans, various perquisites and, in some cases, severance payments. Perquisites, pensions, and severance pay are important, and yet less understood components (Frydman \& Jenter, 2010; Jensen \& Murphy, 1990a). It is difficult to obtain information on these components because of insufficient disclosure. Some authors suggest that the perks may be a signal of weak corporate governance, particularly when firms find ways to conceal the re-porting of perks (Grinstein, Weinbaum, \& Yehuda, 2011). For pensions, the evidence is similar to that of the perquisites (Sundaram \& Yermack, 2007). Executives pay substantial attention to the salary-determination process because salaries comprise a declining percentage of total compensation. Base salaries are key components of executive employment contracts and represent the fixed component in executive contracts. Executives will naturally prefer a dollar increase in base salary to a dollar increase in target bonus or variable compensation, and so the target bonuses, for example, are typically expressed as a percentage of base salary. Each dollar increase in the base salary has positive implications on many other compensation components. Most compensation components are measured relatively to base salary levels, for example, the option grants are expressed as a multiple of base salary.

In the 1980s and 1990s, there was a steady increase in stock option grants within executive compensation, which on a Black-Scholes basis now constitutes the single largest component of CEO pay. Stock options are contracts which give the recipient the right to buy a share of stock at a pre-specified exercise price for a pre-specified term. In other words, the recipient has the option to buy a certain number of company shares for a specified price. Therefore, there is a direct link between managerial rewards and share-price appreciation. The incentives from stock options do not, however, mimic the incentives from stock ownership because only stock-price appreciation is rewarded, as opposed to total shareholder returns. Therefore, the value of options increases with stock-price volatility. Other reason for this is that the options lose incentive value once the stock price falls sufficiently below the exercise price. 
The literature focuses on equity-based compensation paid in the form of restricted stocks, stock options, and other instruments whose value is tied to future equity returns. Equity-based compensation is widely documented in the research examining pay versus performance (Jensen \& Meckling, 1976). Hall and Murphy (2003) and Jensen (2004) stated that the increase in stock options pay is the result of the boards' inability to evaluate the true cost of this form of compensation. The controversy over CEO compensation reflects a perception that CEOs effectively set their own pay levels. In most companies, the last decisions over executive pay are made by members outside the board of directors who are keenly aware of the conflicts of interest between managers and shareholders over the level of pay. However, the CEOs and other top managers exert at least some influence on the level and on the structure of their pay (Jensen \& Murphy, 1990a; Murphy, 1999).

In the substantial heterogeneity across companies and industries, executive bonus plans can be categorized in terms of three basic components: performance measurements, performance standards, and the structure of the pay-performance relation. Hall and Liebman (1998) showed that CEOs are, in fact, not paid like bureaucrats, but that there is a strong relationship between firm performance and CEO compensation. The annual bonus contracts are characterized by discretion. In some firms, boards can use discretion while allocating a fixed bonus, but discretion in this case only affects individual allocations and not the overall amount of the executive payouts. A percentage of their bonus depends on individual performance. Nevertheless, this is a subjective issue because individual performance sometimes includes performance pertaining to some pre-determined objectives or strategic mile-stones. Often the non-financial performance measurement used in annual incentive plans is individual performance with performance measured relatively to pre-established objectives, as well as subjective assessments of individual performance. Other non-financial measurements include customer satisfaction, operational and strategic objectives.

Some research highlights the importance of debt-based compensation as an element of top management contracts, and also the underlying incentive and governance implications of these schemes. Debt-base compensation provides managers with research that includes interesting incentives to reduce the agency cost or debt. Inside debt in the form of pensions also exerts strong influence on the patterns of CEO turnover and other types of compensation (Sundaram \& Yermack, 2007). All this research is based on the assumption that managerial compensations consist of only two components, cash and equity-linked instruments. These authors argue that top managers receive significant compensations from "inside debt" that are pensions and deferred compensations.

In recent years, the use of restricted stock has been increasing due to a combination of reasons. Firstly, a compelling advantage held by stock options was eliminated as companies were required to recognize a charge to earnings on fixed option grants at fair market value. Secondly, publicly traded companies became concerned about the excessive dilution that resulted when the majority of long-term incentives were granted in options. Restricted stock plans offer companies much more design flexibility. Restricted stocks can be criticized mainly because of the dividend equivalents which have to be paid on these stocks prior to the vesting of the stocks. Some authors draw attention to the complete elimination of dividend equivalents, while others insist on its continued use as a way to align the interests of management and shareholders in order to solve agency problems.

EPS (Epstein \& Roy, 2005) is a popular performance metric used in executive compensation contracts (Murphy, 1999; Conyon \& Murphy, 2000). Compensation contracts that tie managerial rewards to EPS create 
explicit incentives for executives to manage the EPS denominator using stock repurchases (over and above any implicit market-based incentives associated with increasing stock-based wealth and improving job security). However, these direct incentives are still absent in compensation contracts that employ non-per-share-based earning metrics, such as return on assets, and non-accounting measurements, such as stock price or qualitative targets linked to personal objectives. Accordingly, the stock repurchases activity will be positively associated with the incidence of EPS-based performance conditions in executive compensation contracts (Core, Guay, \& Verrecchia, 2003; Young \& Jing, 2011). The author argues that the level of dividend payments and the choice between dividends and stock are sensitive to the executives' compensation arrangements. Furthermore, a statistically and economically strong link between stock repurchase activity and the presence of EPS performance conditions in executive compensation contracts is documented.

For Murphy (1999), the levels of pay are higher and pay-performance sensitivities are lower in larger firms. However, the levels of pay and pay-performance sensitivities are lower in regulated utilities than in industrial firms. With that analysis, it was also possible to understand that pay-performance sensitivities are driven primarily by stock options and stock ownership, and not by other forms of compensation.

Bebchuk and Fried (2004) advocated that managerial power has played a key role in shaping managers' pay arrangements. The pervasive role of managerial power can largely explain the contemporary landscape of executive compensation. The managers' influence over their own pay has been the focal point of the criticism on executive compensation in the media and by some shareholders. They argue, with supporting evidence, that when executives have more power, their pay is higher and less sensitive to performance. In their opinion, executive pay is much less sensitive to performance than has been commonly acknowledged (Bebchuk \& Fried, 2004). Other authors study the opportunistic timing of option grants and their relation to firm governance and structure (Berger, Ofek, \& Yermack, 1997; Bebchuk, Cremers, \& Peyer, 2011; Bebchuk, Grinstein, \& Peyer, 2010). Malmendier and Tate (2009), Bertrand and Schoar (2003) study how the type and style of a CEO affect the firm's outcomes. For that, the authors analyzed the CEOs' roles in achieving superstar status to the performance of their firms, and whether and how individual managers are affected by corporate behavior and by performance (Malmendier \& Tate, 2009; Bertrand \& Schoar, 2003). When other sectors were compared, it was possible to confirm that the success of high-tech firms depends more on managing intangible assets. Some of these assets were technology innovation, continuous improvement, software development, and knowledge-based management. High-tech firms must continuously innovate to survive and to sustain their firms' growth (Shim, Lee, \& Joo, 2009).

In summary, it was found that firms are subjected to the agency problem in which the CEO (agent) may not work in favor of the shareholders (principal) to maximize their wealth by improving firm performance. The decisions related to CEO compensation are based on the firms' accounting and finance performance. Therefore, it is theorized that CEO compensation in the function of firm performance in the high-technology with this variables; total assets (ASSETS), employees (EMPL), changes in sales (SALECHG), operating income before depreciation (OIBD), net income before extraordinary items and discontinued operation (NIBEX), earning per share (EPSEX), presented above.

\section{Research Hypotheses}

As previously discussed, existing theories provide predictions on the outlined considerations related to firm value, allowing for two different selection hypotheses. 
The first research question will be:

Hypothesis 1: The CEO compensation is positively correlated with firm performance for high-technology companies in the short term.

Rejection of the null hypothesis would mean that the relative weight in terms of total compensation of each compensation component (such as salary, bonus, stock options and other compensations) are different goals for executives, as opposed to performance in the short term. It might be argued that powerful incentive models are especially valuable for high value firms with high opportunities for growth that need to be decisively and vigorously pursued. It might also be that high value firms are especially likely to attract star CEOs.

Hypothesis 2: The CEO compensation is positively correlated with firm performance in high-technology companies in the long term.

It is possible that high value firms have CEOs with an interest in long-term performance and with obtaining personal benefits in terms of total compensation.

\section{Methodology, Sample, and Data Collection}

The chosen sample is the ExecuComp database, which was used to find the variables and to create a sample of firms between 2004 and 2010. The ExecuComp database provides yearly data on salary, bonus, stock option, and restricted stock grants, as well as managerial stock and option holdings for top executives in firms within the Standard \& Poor's Index (S\&P 500). To test this hypothesis, the following specification is run of the balanced panel of high-technology firms, between 2004 and 2010. High-technology firms are the firms that operate in an industry with a four-digit SIC code of 3570, 3571, 3572, 3576, 3577, 3661, 3674, 4812, 4813, 5045, 5961, 7370, 7371, 7372, or 7373, using the Fama and French classification of 48 industry groups, instead of four-digit SIC (Standard Industrial Classification) codes (Fama \& French, 1997).

According to Bebchuk et al. (2011), in order to test the variables and to assess the above-mentioned research hypotheses there are independent variables that will possibly be used by the regression model to perform the estimation. At an empirical level, this analysis focuses on a sample of 500 high-tech companies in the S\&P index (S\&P500), for the period between 2004 and 2010, which constitutes a sample of 3,356 observations. The ExecuComp database collects information about seven independent variables - total assets (ASSETS), employees (EMPL), changes in sales (SALECHG), operating income before depreciation (OIBD), net income before extraordinary items and discontinued operation (NIBEX), earning per share (EPSEX) - and the independent total compensation (SUMTDC1) variables are listed by year and company.

Several measurements were used as control variables in this study. These include number of employees, assets, increase in sales, the net income, and the EPS, as a proxy of firm size, firm performance and wealth of shareholder, the common predictors of executives' pay.

The High-Tech Dummy (DHTECH) is equal to one if the firm operates in an industry with a four-digit SIC code of 3570, 3571, 3572, 3576, 3577, 3661, 3674, 4812, 4813, 5045, 5961, 7370, 7371, 7372, or 7373, instead of four-digit SIC codes. The main variable of the analysis is SUMTDC1 and it is defined by the sum of the total compensations of the top executives in each company and it includes: salary, bonus, non-equity incentive plan compensation, grant-date fair value of option awards, grant-date fair value of stock awards, deferred compensation earnings reported as compensation, and other compensations. 
Table 1

Executive Compensation Dependent and Independent Variables

\begin{tabular}{|c|c|c|c|}
\hline Name & \begin{tabular}{|l|} 
Expected \\
variation
\end{tabular} & Definition & Units \\
\hline $\begin{array}{l}\text { Ln } \\
\text { (SUMTDC1) }\end{array}$ & $(+)$ & $\begin{array}{l}\text { Ln (the sum of the compensations of top executives includes: salary, bonus, non-equity } \\
\text { incentive plan compensation, grant-date fair value of option awards, grant-date fair value } \\
\text { of stock awards, deferred compensation earnings reported as compensation, and other } \\
\text { compensations). }\end{array}$ & Thousands \\
\hline Ln (ASSETS) & $(+)$ & Ln (the total assets as reported by the company). & Millions \\
\hline Ln (EMPL) & $(+)$ & Ln (employees, the total employees as reported by the company (\#)). & Thousands \\
\hline EPSEX & $(-)$ & EPS (Primary) excluding extraordinary items and discontinued operations. & \\
\hline SALECHG & $(+)$ & The year to year percentage change in Sales. & Percentage \\
\hline Ln (OIBD) & $(+)$ & Ln (the operating income before depreciation as reported by the company). & Millions \\
\hline Ln (NIBEX) & $(+)$ & Ln (the net income before extraordinary items and discontinued operations). & Millions \\
\hline
\end{tabular}

Table 2

Descriptive Statistics

\begin{tabular}{lllllllll}
\hline & SUMTDC1 & ASSETS & EPSEX & OIBD & NIBEX & EMPL & SALECHG & DHTECH \\
\hline Mean & $25,599.88$ & $46,886.07$ & 12.65983 & $3,249.064$ & $1,215.441$ & 46.30875 & 10.80346 & 0.121275 \\
Median & $19,561.74$ & $10,698.19$ & 2.090000 & $1,296.557$ & 507.4820 & 17.59400 & 7.909000 & 0.000000 \\
Maximum & $264,964.7$ & $2,264,909$. & $8,548.000$ & $78,669.00$ & $45,220.00$ & $2,100.000$ & $1,106.400$ & 1.000000 \\
Minimum & 454.4000 & 182.7430 & -37.84000 & -76735.00 & -99289.00 & 0.053000 & -92.68800 & 0.000000 \\
Std. Dev. & $21,706.99$ & $168,685.8$ & 252.8151 & $6,878.305$ & $3,586.554$ & 110.5579 & 30.22776 & 0.326496 \\
Skewness & 3.365542 & 8.450905 & 26.43878 & 4.478257 & -3.906328 & 11.92814 & 15.95401 & 2.320283 \\
Observations & 3,346 & 3,356 & 3,353 & 3,242 & 3,356 & 3,333 & 3,350 & 3,356 \\
\hline
\end{tabular}

The descriptive statistics of the variables for total CEO compensation for high-tech firms are presented in Table 2. In the S\&P500, in the period between 2004 and 2010, there are about 12\% high-technology firms, and it is possible to observe that the group of top executives in each company has a total average compensation around USD 25,600 million. Other interesting finding is that in this period there was not always an increase in sales, but there was a $10.8 \%$ average growth in high-tech companies.

The models presented below were used to test whether firm performance is relevant to ex-plain executive compensation. Firstly, the model for the short term:

Ln $(\mathrm{SUMTDC} 1)_{i t}=a+b_{1} \ln (\mathrm{ASSETS})_{i t}+b_{2} \ln (\mathrm{OIBD})_{i t}+b_{3} \ln (\mathrm{NIBEX})_{i t}+b_{4} \ln (\mathrm{EMPL})_{i t}+b_{5}{ }^{*} \mathrm{ERPSEX}_{i t}+$

$$
b_{6} * \mathrm{SALECHG}_{i t}+u_{i t}
$$

and the secondly, the model for the long term:

$$
\begin{gathered}
\ln (\mathrm{SUMTDC} 1)_{i t}=a+b_{1} \ln (\mathrm{ASSETS})_{i t}+b_{2} \ln (\mathrm{OIBD})_{i t}+b_{3} \ln (\mathrm{NIBEX})_{i t}+b_{4} \ln (\mathrm{EMPL})_{i t}+b_{5} * \mathrm{ERPSEX}_{i t}+ \\
b_{6} * \mathrm{SALECHG}_{i t}+c * \ln (\mathrm{SUMTDC} 1)_{i t-1}+u_{i t}
\end{gathered}
$$

where, $i$ and $t$ represent the year and the company, respectively.

The coefficient $a$ is a constant denoting the base level from which the sum of the compensations of top executive vary according the changes in performance variables.

The panel data model is used as it is the most suitable way of studying a large set of repeated observations and as it assesses evolution over time. With panel data it is possible to simultaneously explore several variations over time and between different individuals. The use of such models has increased immensely and, in fact, combining time and cross-sectional data brings many advantages: It is possible to use a larger number of observations and the degree of freedom in estimates increases, thus making statistical inferences more credible. 
At the same time, the risk of multicollinearity is reduced since the data in companies present different structures. Moreover, this model provides access to further information and the efficiency and stability of the estimators increase, while enabling the introduction of dynamic adjustments (Greene, 2003; Gujarati, 2004).

The regression presented was estimated using the Generalized Least Squares (GLS) with a fixed effect model for time. This means that the regression coefficients which were used with the fixed effect model for explanatory variables do not vary over time. The estimation was conducted assuming that the company's heterogeneity is captured in the constant part and that it differs between companies. The fixed effect model is the most suitable when there is a correlation between errors and variables (Greene, 2003).

In order to assess the above-mentioned research hypotheses, the regression model was used and estimated with fixed effects. The first hypothesis for the positive influence of the CEO compensation in firm performance is presented in Table 3. As it is possible to observe, the regressions are globally significant, with a 5\% significance level. The following table presents the results of the estimation conducted by the generalized method using the fixed effect model for the studied data. The statistics are computed based on a panel data set of 484 firm-year observations, a total of about 2,969 companies that represent $14.08 \%$ of high-technology firms between 2004 and 2010. The total assets, the operating income before depreciation and the net income before extraordinary items and discontinued operations, the growth sales and employment, as reported by companies, are positive (see Table 1 - expected variation) and significantly related to total executive compensations.

Table 3

Results of the Total Executive Compensation Estimation (Regression With SIC Code Dummy (DHTECH) for High-Technology Companies-Econometric Models)

\begin{tabular}{|c|c|c|c|c|c|}
\hline \multicolumn{3}{|c|}{ Dependent variable: LOG (SUMTDC1) } & \multicolumn{3}{|c|}{ Dependent variable: LOG (SUMTDC1) } \\
\hline \multicolumn{3}{|c|}{ Method: Panel EGLS (Period weights) } & \multicolumn{3}{|c|}{ Method: Panel EGLS (Period weights) } \\
\hline \multicolumn{3}{|c|}{ Sample: 20042010 IF OIBD > 0 AND NIBEX > 0} & \multicolumn{3}{|c|}{ Sample: 20042010 IF OIBD > 0 AND NIBEX > 0} \\
\hline \multicolumn{3}{|l|}{ Periods included: 7} & \multicolumn{3}{|l|}{ Periods included: 7} \\
\hline \multicolumn{3}{|c|}{ Cross-sections included: 484} & \multicolumn{3}{|l|}{ Cross-sections included: 484} \\
\hline \multicolumn{3}{|c|}{ Total panel (unbalanced) observations: 2969} & \multicolumn{3}{|c|}{ Total panel (unbalanced) observations: 2969} \\
\hline \multicolumn{3}{|c|}{ Linear estimation after one-step weighting matrix } & \multicolumn{3}{|c|}{ Linear estimation after one-step weighting matrix } \\
\hline Variable & Coefficient & Prob. & Variable & Coefficient & Prob. \\
\hline $\mathrm{C}$ & 7.279001 & 0.0000 & $\mathrm{C}$ & 7.302197 & 0.0000 \\
\hline LOG (ASSETS) & 0.054566 & 0.0002 & LOG (ASSETS) & 0.054500 & 0.0002 \\
\hline EPSEX & -0.000620 & 0.0000 & LOG (ASSETS)*DHTECH & 0.014395 & 0.0000 \\
\hline LOG (OIBD) & 0.204273 & 0.0000 & EPSEX & -0.000619 & 0.0000 \\
\hline LOG (NIBEX) & 0.069080 & 0.0003 & LOG (OIBD) & 0.200525 & 0.0000 \\
\hline LOG (EMPL) & 0.044388 & 0.0000 & LOG (NIBEX) & 0.070401 & 0.0002 \\
\hline SALECHG & 0.002650 & 0.0000 & LOG (EMPL) & 0.043644 & 0.0000 \\
\hline \multirow[t]{2}{*}{ DHTECH } & 0.140800 & 0.0000 & SALECHG & 0.002667 & 0.0000 \\
\hline & \multicolumn{2}{|c|}{ Weighted Statistics } & & \multicolumn{2}{|c|}{ Weighted Statistics } \\
\hline$R$-squared & \multicolumn{2}{|l|}{0.403318} & $R$-squared & \multicolumn{2}{|l|}{0.402732} \\
\hline Adjusted $R$-squared & \multicolumn{2}{|l|}{0.400693} & Adjusted $R$-squared & \multicolumn{2}{|l|}{0.400104} \\
\hline S.E. of regression & \multicolumn{2}{|l|}{0.553285} & S.E. of regression & \multicolumn{2}{|l|}{0.553552} \\
\hline$F$-statistic & \multicolumn{2}{|l|}{$1,536,448$} & $F$-statistic & \multicolumn{2}{|l|}{$1,532,713$} \\
\hline Prob (F-statistic) & \multicolumn{2}{|l|}{0.000000} & $\operatorname{Prob}(F$-statistic $)$ & \multicolumn{2}{|l|}{0.000000} \\
\hline
\end{tabular}

As expected, EPS is negative and significantly related by total compensation in high-tech companies. This 
indicates that there are no explicit contractual arrangements linking compensations and EPS. The performance ratio of firms measured by return has a negative influence. Note that around $40.4 \%\left(R^{2}=0.404\right)$ of the variance in degree of CEO compensation can be explained by the group of variables for short term (see Table 3). Yet, it is important to highlight that around $60.6 \%\left(R^{2}=0.606\right)$ of the variance in degree of CEO compensation for long term, can be explained by the group of variables (see Table 4). These indicate that variables addressed here play a significant role in explaining executive compensation for short- and long-term periods as stated by Chi-Square test $(P$-value $=0)$.

Table 4

Results of the Total Executive Compensation Estimation (Regression With SIC Code Dummy (DHTECH) for High-Technology Companies-Econometric Models)

\begin{tabular}{|c|c|c|c|c|c|}
\hline \multicolumn{3}{|c|}{ Dependent variable: LOG (SUMTDC1) } & \multicolumn{3}{|c|}{ Dependent variable: LOG (SUMTDC1) } \\
\hline \multicolumn{3}{|c|}{ Method: Panel EGLS (Period weights) } & \multicolumn{3}{|c|}{ Method: Panel EGLS (Period weights) } \\
\hline \multicolumn{3}{|c|}{ Sample: 20042010 IF OIBD > 0 AND NIBEX > 0} & \multicolumn{3}{|c|}{ Sample: 20042010 IF OIBD > 0 AND NIBEX > 0} \\
\hline \multicolumn{3}{|l|}{ Periods included: 6} & \multicolumn{3}{|l|}{ Periods included: 6} \\
\hline \multicolumn{3}{|c|}{ Cross-sections included: 483} & \multicolumn{3}{|l|}{ Cross-sections included: 483} \\
\hline \multicolumn{3}{|c|}{ Total panel (unbalanced) observations: 2,517} & \multicolumn{3}{|c|}{ Total panel (unbalanced) observations: 2,517} \\
\hline \multicolumn{3}{|c|}{ Linear estimation after one-step weighting matrix } & \multicolumn{3}{|c|}{ Linear estimation after one-step weighting matrix } \\
\hline Variable & Coefficient & Prob. & Variable & Coefficient & Prob. \\
\hline $\mathrm{C}$ & 3.372131 & 0.0000 & $\mathrm{C}$ & 3.379249 & 0.0000 \\
\hline LOG (SUMTDC1(-1)) & 0.545348 & 0.0000 & LOG (SUMTDC1(-1)) & 0.545797 & 0.0000 \\
\hline LOG (ASSETS) & 0.026126 & 0.0388 & LOG (ASSETS) & 0.026164 & 0.0387 \\
\hline EPSEX & -0.000275 & 0.0000 & LOG (ASSETS)*DHTECH & 0.006955 & 0.0177 \\
\hline LOG (OIBD) & 0.085650 & 0.0006 & EPSEX & -0.000274 & 0.0000 \\
\hline LOG (NIBEX) & 0.029623 & 0.0787 & LOG (OIBD) & 0.083758 & 0.0007 \\
\hline LOG (EMPL) & 0.021974 & 0.0086 & LOG (NIBEX) & 0.030160 & 0.0733 \\
\hline SALECHG & 0.003060 & 0.0000 & LOG (EMPL) & 0.021637 & 0.0096 \\
\hline \multirow[t]{2}{*}{ DHTECH } & 0.066078 & 0.0138 & SALECHG & 0.003064 & 0.0000 \\
\hline & \multicolumn{2}{|c|}{ Weighted statistics } & & \multicolumn{2}{|c|}{ Weighted statistics } \\
\hline$R$-squared & 0.606381 & & $R$-squared & 0.606318 & \\
\hline Adjusted $R$-squared & 0.604336 & & Adjusted $R$-squared & 0.604273 & \\
\hline S.E. of regression & 0.440828 & & S.E. of regression & 0.440872 & \\
\hline$F$-statistic & $2,966,106$ & & $F$-statistic & $2,965,326$ & \\
\hline Prob ( $F$-statistic) & 0.000000 & & $\operatorname{Prob}(F$-statistic $)$ & 0.000000 & \\
\hline
\end{tabular}

\section{Conclusion and Future Researches}

The main purpose of this study was to examine whether the total remuneration paid to CEOs in high-technology firms in the S\&P 500 is related to corporate finance. This work aims at contributing to explaining the influence that performance has on CEO compensation in these companies.

In conclusion, according to the results that were obtained there is empirical evidence to state that in high-technology firms in the S\&P 500, during the period between 2004 and 2010, performance determined total CEO compensation in short- and long-term periods. Results suggest that high-tech firms tend to use more sophisticated performance measurements to determine CEO compensation.

This study only focuses on high-technology firms in the S\&P 500 in the period between 2004 and 2010. The definition of high-technology used in this study can be extended by including other important items, such 
as value of $R \& D$ expenditures, number of patents by firm and citation of patents. Additionally, the findings of this study could only be generalized to other sectors at an international level similarly to those in this research. Furthermore, it will be necessary to focus on the comparison between high-technology firms from other sectors at an international level.

In the future, it will be important to analyze other developments, such as the short- and long-run effect of executive compensation. Furthermore, it will also be important to increase the data sample for the period between 2000 and 2010 in order to broaden the period of analysis and to investigate the effect of the financial crisis in 2008.

Innovation constitutes an indispensable component of corporate strategies. For that, further considerations on innovation measurements may be incorporated in order to analyze the real motivation of the CEO. Further developments on this work will include new variables for the other research hypotheses, including returns to measure firm performance, firm expenditures on research and development, number of patents granted, and degree of openness. These variables and others may be the best proxies to measure the behavior of innovation and the link between executive compensation and firm performance. This paper will provide better understanding on the relationship between compensation and performance in high-technology firms, something which is often discussed in the literature.

\section{References}

Adams, R. B., Almeida, H., \& Ferreira, D. (2005). Powerful CEOs and their impact on corporate performance. Review of Financial Studies, 18(4), 1403-1432.

Bebchuk, L. A., \& Fried, J. M. (2004). Pay without performance: The unfulfilled promise of executive compensation. Cambridge, M.A.: Harvard University Press.

Bebchuk, L. A., Cremers, M., \& Peyer, U. (2011). The CEO pay slice. Journal of Financial Economics, 102, 199-221.

Bebchuk, L. A., Grinstein, Y., \& Peyer, U. R. S. (2010). Lucky CEOs and lucky directors. The Journal of Finance, 65(6), 2363-2401.

Bebchuk, L., Cohen, A., \& Ferrell, A. (2009). What matters in corporate governance? Review of Financial Studies, 22(2), 783-827.

Berger, P. G., Ofek, E., \& Yermack, D. L. (1997). Managerial entrenchment and capital structure decisions. The Journal of Finance, 52(4), 1411-1438.

Bertrand, M., \& Schoar, A. (2003). Managing with style: The effect of managers on firm policies. Quarterly Journal of Economics, 118(4), 1169-1208.

Conyon, M. J., \& Murphy, K. J. (2000). The prince and the pauper? CEO pay in the United States and United Kingdom. The Economic Journal, 110, 640-671.

Core, J. E., Guay, W. R., \& Verrecchia, R. E. (2003). Price versus non-price performance measures in optimal CEO compensation contracts. The Accounting Review, 78(4), 957-981.

Cremers, K. J. M., \& Nair, V. B. (2005). Governance mechanisms and equity prices. The Journal of Finance, 60, $2859-2894$.

Epstein, M. J., \& Roy, M. J. (2005). Evaluating and monitoring CEO performance: Evidence from US compensation committee reports. Corporate Governance, 5(4), 75-87.

Fama, E. F., \& French, K. R. (1997). Industry costs of equity. Journal of Financial Economics, 43(2), 153-193.

Frydman, C. (2009). Learning from the past: Trends in executive compensation over the 20th century. CESifo Economic Studies, 55(3-4), 458-481.

Frydman, C., \& Jenter, D. (2010). CEO compensation. National Bureau of Economic Research Working Paper Series.

Greene, W. H. (2003). Econometric analysis. New Jersey: Prentice hall.

Grinstein, Y., Weinbaum, D., \& Yehuda, N. (2011). The economic consequences of perk disclosure. SSRN eLibrary, Unpublished working paper, Johnson Sch. Res. Paper Series, No. 06-2011.

Gujarati, D. N. (2004). Basic econometrics. New York: McGraw-Hill.

Hall, B. J., \& Liebman, J. B. (1998). Are CEOs really paid like bureaucrats? Quarterly Journal of Economics, 113(3), 653-691. 
Hall, B. J., \& Murphy, K. J. (2003). The trouble with stock options. Journal of Economic Perspectives, 17, 49-70.

Jensen, M. C. (2004). Agency costs of overvalued equity. ECGI-Finance Working Paper No. 39/2004.

Jensen, M. C., \& Murphy, K. J. (1990a). Performance pay and top-management incentives. Journal of Political Economy, 98(2), 225-264.

Jensen, M. C., \& Murphy, K. J. (1990b). CEO incentives: It's not how much you pay, but how. Harvard Business Review, 3 , 138-153.

Jensen, M., \& Meckling, W. (1976). Theory of the firm: Managerial behaviour, agency costs, and ownership structure. Journal of Financial Economics, 3(4), 308-360.

Makri, M., Lane, P. J., \& Gomez-Mejia, L. R. (2006). CEO incentives, innovation, and performance in technology-intensive firms: A reconciliation of outcome and behavior-based incentive schemes. Strategic Management Journal, 27(11), 1057-1080.

Malmendier, U., \& Tate, G. (2009). Superstar CEOs. The Quarterly Journal of Economics, 124(4), 1593-1638.

Maxim, B., Shleifer, A., \& Vishny, R. W. (1996). A theory of privatisation. The Economic Journal, 106, 309-319.

Murphy, K. J. (1999). Chapter 38 executive compensation. In C. A. Orley, \& C. David (Eds.), Handbook of Labor Economics, 3 , 2485-2563.

Shim, E. S., Lee, J., \& Joo, I. K. (2009). CEO compensation and US high-tech and low-tech firms' corporate performance. Contemporary Management Research, 5, 93-106.

Sundaram, R. K., \& Yermack, D. (2007). Pay me later: Inside debt and its role in managerial compensation. Journal of Finance, 62, 1551-1588.

Young, S., \& Jing, Y. (2011). Stock repurchases and executive compensation contract design: The role of earnings per share performance conditions. Accounting Review, 86(2), 703-733. 